\title{
Effect of Deficit Irrigation on Common Bean (Phaseolus vulgaris L.) Under Conventional, Fixed and Alternate Furrow Irrigation Systems at West Wellega, Ethiopia
}

\author{
Robel Admasu*1 Zelalem Tamiru² \\ 1.Jimma Agricultural Research Center P. Box 192, Jimma, Ethiopia \\ 2.Haru Agricultural Research Sub-Center, P. Box 192, Jimma, Ethiopia
}

\begin{abstract}
Improving water use efficiency is one important strategy for addressing future water scarcity, which is driven particularly by increasing human population. Enhancing agricultural water productivity is a critical response as it is by far the main consumer of global fresh water. This study investigated the response of common bean (Phaseolus vulgaris L.) to moisture deficit under conventional, alternate and fixed furrow irrigation system over a three years period. A field experiment was conducted at Haru Agricultural Research sub-center. A randomized complete block design (RCBD) with three replications was used. nine treatments which combined and imposed at all growth stages were used. The three years combined result indicated that there were a highly significant $(\mathrm{P}<0.01)$ variation among treatments for grain yield, above ground dry biomass yield, plant height and water productivity. The grain yield of common bean was significantly $(\mathrm{P}<0.01)$ affected due to moisture deficit and irrigation methods. Accordingly, the highest grain yield was obtained from conventional furrow 100\% ETc irrigating all growth stage treatment followed by conventional furrow $75 \%$ ETc and $50 \%$ ETc. The highest water productivity of $0.84 \mathrm{~kg} \mathrm{~m}^{-3}$ was obtained from alternate irrigation system at $75 \%$ ETc but the yield loss is not tolerable. conventional furrow 75\% ETc and conventional furrow 50\% ETc gave a better yield with a moderate water productivity. Therefore, for better water productivity without a significant yield loss, it is recommended to use conventional furrow irrigation with $75 \%$ ETc and conventional furrow irrigation $50 \%$ ETc. In addition, if the water resource is not scarce in the area, it is recommended to use conventional furrow irrigation with $100 \%$ ETc throughout the whole growth stage to obtain optimum yield.
\end{abstract}

Keywords; Water productivity, Deficit irrigation, ETc, Furrow irrigation system, common bean

DOI: $10.7176 / \mathrm{JNSR} / 9-1-04$

\section{Introduction}

Global population growth especially in developing countries forces to increase food production. Tis needs di erent strategies like an intensification of modern agricultural crop production and increasing farm area. However, this could not be only depending on rain-fed agriculture as the climate change scenario and limited area to produce a crop in only rainy season. The challenge of crop production in rain-fed is aggravated by temporal and special variation of rainfall and further accelerated by climate changes (Pereira et al., 2009). The increasing need for crop production due to the growing population in the world is necessitating a rapid expansion of irrigated agriculture throughout the world (Awulachew et al., 2005). However, climate change has also contributed significantly to the water scarcity problem (WHO, 2009). Rising temperatures increase the rate of evaporation from land and surface water resources; this has caused reductions in river run-off in several areas. Therefore, the problem of water availability for food production has had, and will continue to have, environmental and social costs. Land and water resources have been degraded due to the expansion of irrigation networks and on-farm mismanagement of irrigation water.

Many investigations have been conducted to gain experiences in irrigation of crops to maximize performances, efficiency and profitability. However, investigations in water saving irrigation still are continued (Sleper et al., 2007). A recent innovative approach to save agricultural water is deficit irrigation (DI). Deficit irrigation provides a means of reducing water consumption while minimizing adverse effects on yield (Mermoud et al., 2005). Deficit irrigation consists of finding the optimum balance between water use and crop yield. Under DI, crop producers allow the crop to experience some water stress, but the water saved should allow an increase in the area irrigated, or it could be put to more productive use. ICARDA has shown that a $50 \%$ reduction in irrigation water applied decreased yields by 10 to $15 \%$, and overall farm productivity increased by $38 \%$ when the water saved was used on other land (Pereira et al., 2002).

Common bean is one of the most important pulse crops in Ethiopia, due to its richness in protein content. It is also an important crop in crop rotation due to its fixation of atmospheric nitrogen, organic matter and improving water use efficiency of the cropping system (pala et al., 1994). it has a shallow rooting system and require frequent irrigation (Weaver et al., 1984). Therefore, this crop may respond strongly to water deficit (Teran and Singh, 2002; Nunez-Barrios et al., 2005; Munoz-Perea et al., 2006). There are reports that common bean is susceptible to drought stress or water deficit and it has been reported accelerated maturity of 
crop along with reducing grain yield and mean weight of hundred seeds following water stress, have been reported (Nielsen et al., 1998 and Molina et al., 2001). Furthermore, common bean cultivar has reported to respond differently to soil moisture stress depending on the severity of water stress (Boutraa et al., 2001). Payero et al., (2008) reported that water deficit can affect growth, development and physiological processes of maize plants, which reduce biomass yield. However, there is a gap on water productivity enhancement and the critical moisture deficit level for optimal production which can help to face the challenge occurs due to water scarcity.

Therefore, determination of the effect of deficit irrigation on water productivity is important to utilize the limited water resource without significantly affecting irrigated crop yield. Considering the scarcity of irrigation water, this research was aimed to determine the effect of moisture deficit on water productivity of irrigated common bean.

\section{Materials and Methods}

\section{Description of the experimental area}

The experiment was conducted at Haru agricultural research sub-center during the growing season of 2016 and 2015. It was found in west Wellega zone Gimbi area. The rainfall pattern of the area is bimodal with a short rainy season from February to March and the main rainy season from June to September. The most dominant soil type of the area is clay loam.

\section{Treatments and design}

A field experiment was carried out in three seasons of 2016 and 2018. Randomized Complete Block Design (RCBD) with three replications was used following the procedure of Gomez and Gomez (1984). Nine treatments of different deficit irrigation level were factorially combined and randomized in plots as shown in Table 1 . The optimal irrigation schedule (ETc) was computed with Cropwat model.

Table 1 - Experimental treatments combinations

\begin{tabular}{|l|l|}
\hline Number & Treatments \\
\hline 1 & Alternate furrow $100 \%$ ETc \\
\hline 2 & Alternate furrow $75 \%$ ETc \\
\hline 3 & Alternate furrow $50 \%$ ETc \\
\hline 4 & Fixed furrow $100 \%$ ETc \\
\hline 5 & Fixed furrow $75 \%$ ETc \\
\hline 6 & Fixed furrow $50 \%$ ETc \\
\hline 7 & Conventional furrow $100 \%$ ETc (Check) \\
\hline 8 & Conventional furrow $75 \%$ ETc \\
\hline 9 & Conventional furrow $50 \%$ ETc \\
\hline
\end{tabular}

Each individual plot had area of $3 \mathrm{~m} \mathrm{X} 3 \mathrm{~m}=9 \mathrm{~m}^{2}$, which consists of 6 rows. Goberasha common bean variety (Phaseolus vulgaris L.) was used as seed source. The recommended spacing of 60 and $10 \mathrm{~cm}$ between row and plant was employed. Each experimental treatment was fertilized with recommended fertilizer application, that was $100 \mathrm{~kg} / \mathrm{ha}$ and $100 \mathrm{~kg} / \mathrm{ha}$ of DAP and Urea, respectively. All cultural practices were done to all treatments in accordance to the recommendation made for the area. Irrigation water was applied as per the treatment to refill the crop root zone depth close to field capacity.

\section{Data collected}

Yield and growth parameter were recorded and the treatments were compared based on grain yield and growth parameter, which includes plant height, above ground biomass and grain yield. Also, water productivity of the crop was estimated.

Grain yield was calculated by harvesting the total number of plants in the net plot $\left(3.75 \mathrm{~m}^{2}\right)$ and grain yield per plot was measured using electronic balance and then adjusted to $10.0 \%$ moisture and converted to hectare basis. Above ground biomass was determined by harvesting all the plants from the net plot area at physiological maturity and weighed after sun drying to a constant weight and converted to hectare basis. The water productivity was calculated by the ratio of harvested yield per total water used.

$W p=\frac{\text { Harvested grain yield }}{\text { Total water used }}$

The data were statistically analyzed combined for all years by SAS software. SAS software version 9.2 for windows was used for analysis (SAS Institute, 1996). Whenever the treatment effects were found significant, GLM test at 1 and 5\% was performed to assess significant difference among treatments means.

\section{Result and Discussion}

Plant height

The statistical analysis showed that different deficit irrigation levels had a highly significant $(\mathrm{P}<0.01)$ effect on 
plant height (Table 2). The maximum plant height was observed at conventional furrow 100\% ETc followed by conventional furrow 75\% ETc (Table 2). Whereas, the minimum was obtained from fixed furrow 50\% ETc. From the current finding, plant height was decreased as a soil moisture content in the root zone decreased. This probably is a natural result of the effect of water deficit resulting from the cell elongation and division, and reflected on the elongation of stem internode (Hillel, 1990). The increasing plant height with adequate depth of irrigation application also indicate the favorable effect of water in maintaining the turgor pressure of the cell which is the major prerequisite for growth (Vaux and Pruit, 1983). On the contrary, shortening of plant height under soil moisture stress may be due to stomata closure and reduced $\mathrm{CO} 2$ and nutrient uptake by the plants and, hence, photosynthesis and other biochemical process are hampered, affecting plant growth (El-Noemani et al., 2009). In addition, the plant height shows a decreasing trend for the different furrow irrigation system, the maximum was from conventional furrow irrigation method followed by alternate furrow and fixed furrow irrigation methods (Table 2). Webber et al., (2006) found that common bean (Phaseolus vulgaris) is not well suited to water deficit conditions and alternate furrow irrigation as green gram (Mung bean). Rosadi et al., (2005) revealed that a small level difference in moisture deficit levels did not affect plant height, whereas, it affects when the moisture deficit levels was so high which agrees with the current finding. Emam et al., (2010) and Shenkut and Brick (2003) reported that plant height is affected by severe influence from environmental factors such as water stress.

\begin{abstract}
Above ground dry bio-mass
Different deficit levels and furrow application method has a significant influence $(\mathrm{p}<0.01)$ on dry above ground biomass yield. The mean dry biomass at different deficit level showed decreasing trend due to decreasing of irrigation water applied. From table 2, the maximum above ground dry biomass was obtained from conventional furrow $100 \%$ ETc followed by conventional furrow $75 \%$ ETc. Whereas, the minimum was obtained from fixed furrow 50\% ETc (Table 2). From the present study the trend of dry above ground biomass production fairly decreasing as the amount of water applied decreases. This is due to higher biomass production for well irrigated plots since irrigation was applied based on crop water requirement and moisture stress is reduced. Emam et al., (2010) reported that plant dry weight was decreased significantly by increasing water stress. Similar results were reported in the study by Karam et al., (2005). They reported that the applied irrigation water amount reduced dry matter accumulation also reduced. Greater accumulation of dry matter is one of the important inputs to assure total translocation of photosynthate materials to the seed. As reported by several researchers, if water is a deficit factor, there will be a retarded growth in the vegetative and reproductive parts of plants. Terán and Singh (2002) indicated that shoot biomass accumulation is considered as an important trait to attain high seed yield in seed legumes. On the other hand, water deficit can decrease plant height and total biomass (Terán and Singh (2002) and White et al., (1994)) also observed that water deficit retarded plant growth which in turn resulted in production of low biomass and, hence, low grain yield. In addition, the furrow irrigation methods showed a significant difference on above ground dry biomass. Conventional furrow irrigation system is a superior one followed by alternate furrow irrigation and fixed furrow irrigation (Table 2). Mulugeta Mohammed and Kannan Narayanan (2015) and Meskelu et al., (2018) revealed that maize above ground dry biomass is higher for conventional furrow irrigation system than alternate and fixed furrow irrigation system. Over all plant growth is a process of biomass accumulation and is a consequence of the interaction of photosynthesis, respiration, longdistance transport, water relations and mineral nutrition processes. Water deficit stress affects these processes considerably. Many other researchers have also showed that water deficit decreased biomass production of different crops.
\end{abstract}

\title{
Grain yield
}

The three years over year analysis of grain yield shows a highly significant difference $(\mathrm{P}<0.01)$ on the use of different furrow system as well as on different deficit levels of irrigation. The result revealed that conventional furrow $100 \%$ ETc gave the highest grain yield $\left(2393.5 \mathrm{~K} . \mathrm{g} \mathrm{ha}^{-1}\right)$ followed by conventional furrow $75 \%$ ETc $\left(2053.7 \mathrm{~K} . \mathrm{g} \mathrm{ha}^{-1}\right)$ (Table 2). The minimum grain yield was obtained from fixed furrow 50\% ETc $\left(822.3 \mathrm{~K} . \mathrm{g} \mathrm{ha}{ }^{-1}\right)$ followed by alternate furrow $50 \%$ ETc $\left(900.5 \mathrm{~K}_{\mathrm{g} \mathrm{ha}} \mathrm{g}^{-1}\right)$ (Table 2). The interesting finding from the present study is conventional furrow irrigation $75 \%$ ETc had a minimum yield loss $(14.75 \%)$ over the control treatment. The result indicated that the irrigation water applied to the highest yielding treatment next to the control was $25 \%$ less than that of applied to the control. As the moisture deficit level increased up to $75 \%$ of the control one the yield loss goes up to $65.65 \%$ on fixed furrow irrigation water application method. It is well known that the ultimate effect of drought in legumes and cereals is reduction of grain yield. In the present study, the stress at the $75 \%$ deficit had affected seed yield so severely, far from normal size and weight and also shriveled in morphology. Simsek et al., 2011 revealed that when the moisture deficit levels increased the seed production of the common bean cultivars reduced significantly. The findings of this study agree with the findings of most researchers, who had proved the fact that water deficit can decrease seed yield to the different levels depending 
on the extent of the stress and on growth stage at which the stress occurred. Ghassemi-Golezani et al., (2009) obtained a $20 \%$ yield reduction with stress during early and late vegetative growth and $50 \%$ reduction when stressed during early pod filling stage. Timsina et al., (1993) also reported a yield reduction of 40\% - 89\% in water stressed bean genotypes. Additionally, Taddese and Amare (1994) studied the effects of water limitation on growth and grain filling of faba bean cultivars and found out that water deficit stress considerably reduced grain yields due to large reductions in growth, grain filling duration, grain weight and grains per plant. Researches conducted on maize (Jonghan Ko and Giovanni Piccinni, 2009) and on onion (Enciso et al., 2009) revealed that, as the moisture deficit level increased the production of the crop will declined, which agrees with the current finding. When we compare the method of water application conventional furrow is best suited for common bean production, as the irrigation method changed to alternate furrow and fixed furrow the yield loss is become 47.11\% and 52.81\% respectively. Manal and Abdallh (2013) research work on maize revealed that, the highest grain yield was obtained with conventional furrow irrigation while, the lowest yield was obtained with fixed furrow irrigation which agreed with the current finding. As indicated by many researchers, water stress decreases the final leaf area, net photosynthesis, light use efficiency (Egli, 1998, Husain et al., 1990 and Grashoff, 1990), pod retention and filling by reducing the availability of assimilates and distorting hormonal balance (Hura et al., 2007) and final yield reduction will be the consequence.

\section{Water productivity}

From the results of analysis of variance (Table 2), there were highly significant difference at $(\mathrm{P}<0.01)$ between the three irrigation systems in water productivity. This is because of the difference in percentage of water actually converted to evapotranspiration out of the total amount applied. This is consistent with the significant improvements in water productivity that have been associated with alternate furrow irrigation (Zhang et al., 2000). From the table 2, the maximum water productivity obtained from alternate furrow $75 \%$ ETc followed by fixed furrow $75 \%$ ETc. whereas, the minimum was obtained from fixed furrow $50 \%$ ETc. From the current study, the maximum water productivity was obtained at $66.5 \%$ of soil moisture deficit from the control treatment, as a moisture deficit level increased up to $75 \%$ of the control one the water productivity becomes low. The reason for this finding is may be the grain yield produced by the applied water is very low because of a high level of moisture stress generated in the root zone. Different research conducted by Kirnak et al., (2005) and Sarkar et al., (2008) stated that higher water productivity will be obtained on maximum water deficit level which contradict with the current findings. Yalew (2007) investigated that although yield increment is generally accompanied with an increase in the total water use, higher water productivity was recorded with the deficit application.

Table 2. Effect of deficit and furrow irrigation systems on yield and water productivity

\begin{tabular}{|c|c|c|c|c|}
\hline Treatments & $\begin{array}{l}\text { Plant } \\
\text { Height*** } \\
(\mathrm{cm})\end{array}$ & $\begin{array}{c}\text { Dry Bio-mass } \\
\text { Yield*** } \\
\left(\mathrm{t} \mathrm{ha}^{-1}\right)\end{array}$ & $\begin{array}{c}\text { Grain } \\
\text { Yield }^{* * *} \\
\left(\mathrm{~K} \mathrm{~g} \mathrm{ha}^{-1}\right)\end{array}$ & $\begin{array}{c}\text { Water } \\
\text { Productivity*** } \\
\left(\mathrm{K} . \mathrm{g} \mathrm{ha}^{-1}\right)\end{array}$ \\
\hline Alternate furrow $100 \%$ ETc & $67.77^{\mathrm{c}}$ & $4.77^{\mathrm{c}}$ & $1265.9^{d}$ & $0.52^{\mathrm{bc}}$ \\
\hline Alternate furrow $75 \% \mathrm{ETc}$ & $63.60^{\mathrm{d}}$ & $4.22^{\mathrm{d}}$ & $1129.3^{\mathrm{f}}$ & $0.84^{\mathrm{a}}$ \\
\hline Alternate furrow $50 \%$ ETc & $55.18^{\mathrm{f}}$ & $3.74^{\mathrm{e}}$ & $900.5^{\mathrm{gh}}$ & $0.49^{\mathrm{cd}}$ \\
\hline Fixed furrow $100 \%$ ETc & $60.20^{\mathrm{e}}$ & $4.13^{\mathrm{d}}$ & $1129.3^{\mathrm{e}}$ & $0.46^{\mathrm{d}}$ \\
\hline Fixed furrow $75 \%$ ETc & $52.63^{\mathrm{g}}$ & $3.64^{\mathrm{e}}$ & $979.5^{\mathrm{fg}}$ & $0.80^{\mathrm{a}}$ \\
\hline Fixed furrow $50 \%$ ETc & $44.72^{\mathrm{h}}$ & $3.21^{\mathrm{f}}$ & $822.0^{\mathrm{h}}$ & $0.45^{\mathrm{d}}$ \\
\hline Conventional furrow $100 \%$ ETc & $81.43^{\mathrm{a}}$ & $6.13^{\mathrm{a}}$ & $2393.5^{\mathrm{a}}$ & $0.49^{\mathrm{cd}}$ \\
\hline Conventional furrow $75 \%$ ETc & $71.67^{\mathrm{b}}$ & $5.53^{\mathrm{b}}$ & $2053.7^{\mathrm{b}}$ & $0.56^{\mathrm{b}}$ \\
\hline Conventional furrow $50 \%$ ETc & $67.37^{\mathrm{c}}$ & $4.72^{c}$ & $1368.8^{\mathrm{c}}$ & $0.56^{\mathrm{b}}$ \\
\hline LSD at 0.01 & 1.74 & 0.14 & 90.14 & 0.044 \\
\hline $\mathrm{CV} \%$ & 7.36 & 10.69 & 6.56 & 8.8 \\
\hline
\end{tabular}

Means with the same column followed by the same letters are not significantly different. *significant $(\mathrm{p}<0.05)$, $* *$ significant $(\mathrm{p}<0.01),{ }^{*} * *$ significant $(\mathrm{p}<0.001),{ }^{\mathrm{ns}}$ not significant $(\mathrm{p}<0.05)$.

\section{Conclusion and Recommendation}

The result of this study confirm that water availability plays a major role in plant height, dry above ground biomass and grain yield weight of growing common bean. Common bean production depends mainly on soil water condition. A high level of soil water availability usually ensures an optimal common bean growth. Any restriction in the supply of irrigation water induces decrease plant growth. Overall, as a moisture deficit level increased the grain yield, above ground dry bio-mass yield and plant height decreased. On water productivity issue, as a moisture deficit level increased as mid stress level the water productivity enhanced, whereas, when the deficit level goes to sever moisture stress level the water productivity becomes minimum. Regarding of furrow irrigation methods, there were major differences among conventional, alternate and fixed irrigation in terms of studied traits. Regarding less water consumption of alternate and fixed irrigation compared with 
conventional irrigation under mild and severe water stress, these irrigation methods are more water efficient than conventional irrigation. The result of the study confirms these ideologies. Therefore, for effective utilization of irrigation water and optimum growth of common bean cultivars, conventional furrow $75 \%$ water treatment level is advisable for farmers to use so as to avoid wastage of water.

\section{Acknowledgment}

The Authors are thankful to staff of Jimma Agricultural Research Center in general for providing necessary support to conduct the study. Our special thanks also go to Ethiopian Institute of Agricultural Research (EIAR) for financial support to conduct the study in particular, researcher as well as technicians in the natural resource directorate.

\section{Reference}

Awulachew, S.B., Merrey, D.J., Kamara, A.B., Van Koopen, B., De Vries, F. P. and Boelle, E. 2005. Experiences and Opportunities for Promoting Small-Scale/Micro Irrigation and Rainwater Harvesting for Food Security in Ethiopia. IWMI. Working Paper 98, 2005.

BoutraaT, Sanders FE (2001). Influence of water stress on grain yield and vegetative growth of two cultivars of bean (Phaseolus vulgaris L) J Agronomy and crop science 187: 251-275.

Egli, D.B. (1998) Seed Biology and the Yield of Grain Crops. CAB International, Wallingford, 47.

El-Noemani, A. A., Aboamera, O.M., Aboellil., and Dewedar. 2009. Growth, yield, quality and water use efficiency of pea plant as affected by evapotranspiration and sprinkler height. Journal of Agricultural Research, 34: 1445-1466.

Emam y, Shekoofa F, Salehi, Jalali, AH (2010) Water Stress Effects on Two Common Bean Cultivars with Contrasting Growth Habits. College of Agriculture, Shiraz University, Shiraz, Iran, American-Eurasian J Agriculture \& Environmental Science 9 (5): 495-499.

Enciso J., B. Wiedenfeld, J. Jifon, and S. Nelson (2009). Onion yield and quality response to two irrigation scheduling strategies. ELSEVER Scientia Horticulturae 120 (2009) 301-305

Ghassemi-Golezani, K., Ghanehpoor, S. and Mohammadi-Nasab, A. (2009) Effects of Water Limitation on Growth and Grain Filling of Faba Bean Cultivars. Journal of Food, Agriculture \& Environment, 7, 442-447.

Grashoff, C. (1990) Effect of Pattern of Water Supply on Vicia faba L. II. Pod Retention and Filling, Dry Matter Portioning, Production and Water Use. The Journal of Agricultural Science, 38, 131-143.

Hillel, D. 1990. Role of Irrigiation in Agricultural System. In B. A. Stewart, and D. R. Nielson (eds). Irrigation of Agricultural Crops. ASA. CSSA. Monograph, Madison was. P. 5- 29.

Hura, T., Hura, K., Grzesiak, M. and Rzepka, A. (2007) Effect of Long-Term Drought Stress on Leaf Gas Exchange and Fluorescence Parameters in C3 and C4 Plants. Acta Physiologiae Plantarum, 29, 103-113. http://dx.doi.org/10.1007/s11738-006-0013-2

Husain, M., Reid, J.B., Othman, H. and Gallagher, J.N. (1990) Growth and Water Use of Faba Beans (Vicia faba L.) in a Sub-Humid Climate. I. Root and Shoot Adaptation to Drought Stress. Field Crops Research, 23, 117. http://dx.doi.org/10.1016/0378-4290(90)90093-Q

Jonghan K. and G. Piccinni (2009). Corn yield responses under crop evapotranspiration-based irrigation management. ELSEVER agricultural water management 96 (2009)799-808

Kirnak H, Higgs D, Kaya C, Tas I. 2005. Effects of irrigation and nitrogen rates on growth, yield, and quality of musk melon in semiarid regions. Journal of Plant Nutrition, 28: 621-638.

Manal A.E.N. and A.M. Abdallh (2005). Corn Yield Response to some Irrigation Methods and Fertilization with Macro and Micronutrients. Egypt. J. Soil Sci. Vol. 53, No.3, pp. 347-360 (2013)

Molina JC, Moda Cirino V, Júnior RT, De Faria, Destro D, ( 2001). Response of common bean cultivars and lines to water stress. Crop Breed Applied biotechnology 1: 363-372

Muñoz-Perea, C.G., H. Terán, R. Allen, J.L. Wright, D.T. Westermann and S.P. Singh. 2006. Selection for drought resistance in dry bean landraces and cultivar. Crop Sci. 46. 2111-2120.

Nielsen DC, Nelson NO (1998). Black bean sensitivity to water stress at various growth stages. Crop Science 38 : $422-427$.

Nunez-Barrios, A., G. Hoogenboom and D.S. Nesmith, 2005. Drought stress and the distribution of vegetative and reproductive traits of a bean cultivar. Sci. Agric., 62: 18-22.

Nunez-Barrios, A., G. Hoogenboom and D.S. Nesmith, 2005. Drought stress and the distribution of vegetative and reproductive traits of a bean cultivar. Sci. Agric., 62: 18-22.

Pala JC, mode Corino N, Janior RJ (1994). Response common bean cultivars and lines to water stress. Crop breed Applied biotechnology 1: 363-372.

Pereira LS, Cordery I, Iacovides I (2009) Coping with water scarcity: Addressing the challenges. SSBM.

Rosadi R A B, M.S. Afandi, M. Senge, K. Ito and J.T. Adomako (2005). Critical water content and water stress coeffcient of soybean (Glycine max [L.] Merr.) under defcit irrigation. Paddy and Water Environment 3: 


\section{9-223}

Sarkar, S., S.B. Goswami, S. Mallick and M.K. Nanda. 2008. Different indices to characterize water use pattern of micro-sprinkler irrigated onion (Allium cepa L.). Journal of Agricultural Water Management, 95: 625632.

Shenkut AA, Brick MA (2003) Traits associated with dry edible bean (Phaseolus vulgaris L.) productivity under diverse soil moisture environments. Euphytica 133: 339-347.

Simsek M., N. Comlekcioglu and I. Ozturk (2011). The effects of the regulated deficit irrigation on yield and some yield components of common bean (Phaseolus vulgaris L.) under semi-arid conditions African Journal of Biotechnology Vol. 10(20), pp. 4057-4064, 16 May, 2011

Taddese, M. and Amare, A. (1994) Performance of Sorghum and Bean Genotypes under Stress and Non-Stress Environments. In: Reddy, M.S. and Kidane, G., Eds., Development of Ecologies for the Dry Land Farming Areas of Ethiopia, In: Proceedings of the 1st National Workshop on Dry Land Farming Research, Nazret, 26-28 November 1991, 24-25.

Teran, H. and S.P. Singh, 2002. Comparison of sources and lines selected for drought resistance in common bean. Crop Sci., 42: 64-70.

Terán, H. and Singh, P. (2002) Comparison of Sources and Lines Selected for Drought Resistance in Soy Bean. Crop Science, 42, 62-70. http://dx.doi.org/10.2135/cropsci2002.0064

Timsina, J.M., Garrity, D.D. and Penday, R.K. (1993) Cowpea Water Relations and Growth Response on a Top Sequence Water Table Gradient. Agronomy Journal, 85, 368-378. http://dx.doi.org/10.2134/agronj1993.00021962008500020037x

Vaux, H. J. and W.O.Pruit. 1983. Crop water production function. In: D. Hillel(Ed). Advance irrigation, 12:1693.

Weaver, M.L., H. Ng, D.W. Burke, M.J. Silbernagel, K. Foster and H. Timm, 1984. Effect of soil moisture tension on pod retention and seed yield of beans. HortScience, 19: 567-569.

Webber HA, Madramootoo CA, Bourgault M, Horst MG, Stulina G, Smith DL (2006) Water use efficiency of common bean and green gram grown using alternate furrow and deficit irrigation. Agric. Water Manage. 86(3):259-268

White, J.W., Castillo, J.A., Ehleringer, J.R., Garcia, J.A. and Singh, S.P. (1994) Relations of Carbon Isotope Discrimination and Other Physiological Traits to Yield in Common Bean (Phaseolus vulgaris) under Rainfed Conditions. The Journal of Agricultural Science, 122, 275-284. http://dx.doi.org/10.1017/S0021859600087463

World Health Organization (WHO), 2009. Ten facts about water scarcity. Available at: http://www.who.int/features/factfiles/water/en/index.html. Accessed on 28 Jan. 2013.

Yalew, Z. (2007). Effect of Deficit Irrigation on the Growth and Yield of Maize (Zea may L.): a case study in West Gojjam Administrative Zone, Amhara National Regional State, Ethiopia. MSc. Thesis. Dryland Agronomy. Mekele University, Mekele.

Zhang, J., S. Kang, Z. Liang., Y. Z. Pan, P. Shi, Y. H. Pan, Z. S. Liang, X. T. Hu. 2000. Soil water distribution, uniformity and water use efficiency under alternate furrow irrigation in arid areas. Irrigation Science 19: $181-190$ 